\title{
Improving the Performance of Wheat ( Triticum aestivum L.) by Seed Priming Under Arid Conditions in Kurdistan province of Iraq
}

\author{
Ali Abbas Khraibet Al-Taie \\ Field Crops Department \\ Halabjah Technical College of Applied Sciences \\ Sulaymaniyah Poly Technical University \\ Ministry of higher Education \&Scientific Research-Kurdistan-Iraq \\ Email address : ali_altai_65@yahoo.com Mob. : 009647711186735
}

\begin{abstract}
This study attempted to examine the effect of seed priming using plant growth regulators and vitamin $C$ on some yield traits of three bread wheat cultivars (KALAL2, KUAZ , ADANA) in Kurdistan province of Iraq. The field study was performed three replications as factorial experiment in the form of a completely randomized design. Five priming treatments were use( dry seeds, distilled water, GA (Gibberellin), ( SA) Salicylic acid, AS ( Ascorbic acid))as $50 \mathrm{ppm}$ for each the last three priming factors. The results showed that seed priming decreased the time to germination in all of the priming treatments, with improved length and dry weight of the seedling, final germination percentage.Ascorbic acid have the most positive effective between the other priming treatments. Results also showed an improvement in the field emergence percentage by seed priming, which helped in the development of other field attributes of the yield and its components of the three studied varieties. Adana variety showed a clear superiority over the other two varieties in most studied traits and all the priming factors used in the study. We can conclude from this study that seed priming can be a successful method in both of seedling and yield parameters of wheat, with the adoption of ascorbic acid as an important factor for the priming especially in dry and semi-arid areas.
\end{abstract}

Keywords: Wheat, priming treatments, $\mathrm{GA}_{3}$, Salicylic acid , Ascorbic acid

\section{$\underline{\text { Introduction }}$}

Wheat is an important cereal crop and occupies a significant position in the economy at all over the world, it is a staple food for billions of world inhabitants (1). The cultivated area in Iraq (Including Kurdistan region) in year 2005was (1.5 million hectare) yielded 2.2 million tons with an average $1400 \mathrm{~kg} \mathrm{ha}-1$, this was not sufficient and it is far below than the worlds average of some developed countries such as Germany, Egypt, Mexico and China recording $7282,6251,4404$ and $3729 \mathrm{~kg}$ ha-1 respectively (2).

Drought is one of the greatest constraints on growth and development of wheat especially in the Kurdistan region of Iraq because it depends entirely on most of its regions on the rainfall, which is often the amounts and timing precipitation are irregular in the winter, especially in recent years, the problem of drought and the decline of rainfall during the early stages of wheat cultivation is the main problem that negatively affect the increase of production of this strategic crop .

Field establishment is essential to achieve optimal production of any field crop. Under unfavorable environmental conditions, there will be low seed germination followed by poor field establishment, a common phenomenon in crops, which has proved to be one of the main obstacles to production high yield in field crop plants. 
The need here is to consider improving the performance of germination and emergence under the conditions of the demilitarized zone and the unfavorable conditions, especially in the rainy seasons, and the farmers not to risk seed dispersal and start planting according to the time and quantity of rainfall. This is achieved through crop management and control of agricultural processes to overcome these obstacles. Seed priming technology is one of the methods used to improve the latent performance of the seed in a wide range of environmental conditions. In addition, low precipitation and inadequate moisture of seed zone under rainfall conditions reduces grain yield potential. Therefore, seed priming is a technology that enhances rapid (7-10 d) emergence and early establishment of wheat. Rapid and uniform field emergence is an essential prerequisite at two irrigated and rainfall conditions to reach the yield potential, quality, and ultimately profit in annual crops. Seed priming has been common pretreatment that reduces the time between seed sowing until emergence and synchronizes seedling emergence (3).

The theory of seed priming was proposed by Heydecker in 1973 [4] Seed priming,

a controlled hydration technique that allows the pre-germination metabolisms without actual germination $(5,6)$, is one of the most pragmatic and short-term approaches to combat the effects of drought $(7,8)$ and other environmental stresses $(9,8,11)$ on seedling emergence and stand establishment. Primed seeds usually have higher and synchronized germination (12, $7,6)$ owing to simply a reduction in the lag time of imbibitions (12), build-up of germination enhancing metabolites (14), metabolic repair during imbibition $(15,16)$ and osmotic adjustment $(5)$.

. Various seed priming techniques have been developed which include hydro-priming, halo-priming, osmopriming and hormonal priming etc. Hormonal priming is soaking of seed in hormone solution is referred as hormonal priming. GA3, Salicylic acid, Ascorbic acid, Cytokinins etc can be used for this technique(37)

Plant hormones are active members of the signal cascade involved in the induction of plant stress responses (18). The exogenous application of gibberellic acid $\left(\mathrm{GA}_{3}\right)$ improved tolerance under abiotic stress by induction and increasing of the endogenous levels of salicylic acid (19). Gibberellic Acid $\left(\mathrm{GA}_{3}\right)$ is the most important growth hormone which increases cell growth and elongation, cell division in cambial zone, breaks seed dormancy, promotes seed germination, intermodal length, hypocotyls growth, increases the size of leaves, enable greater photosynthesis and plant metabolism and ultimately increases plant or crop yield under normal as well stress condition. Gibberellic acid has been reported to increase germination percentage and seedling growth (20).

Ascorbic acid (AsA) is regarded as one of the most effective growth regulators against abiotic stresses $(21,22)$ Batool el al., (2012). Azooz et al., (2013) showed that application of ascorbic acid through seed soaking enhanced plants growth by increased germination percentage, root and shoot fresh and dry weights, chlorophyll content and higher accumulation osmolytes. Ascorbic acid (AsA), another important organic molecule serves as detoxification of reactive oxygen species $(23,24)$ and a co-factor for many enzymes $(25)$. It is also involved in biosynthesis of many other plant hormones, including ethylene, gibberellic acid, and abscisic acid (26). Ascorbic acid (AsA) is one of the important metabolites involved in cell division, osmotic adjustment( 27$)$ and also plays vital role during the initial stages of germination (28). Ascorbic acid also possesses strong antioxidant potential and helps in balancing the production and scavenging of $\operatorname{ROS}(29,30)$; however; high endogenous AsA level is required to maintain the balance. Interestingly, exogenous application of AsA can increase the endogenous AsA level (31). Application of AsA through seed priming may thus be helpful in improving the stand establishment and allometry of wheat under drought.

Salicylic acid (SA), an endogenous growth regulator of phenolic nature influences many physiological processes such as, seed germination (32), ion permeability (33), photosynthesis and plant growth rate $(34,35,36)$. Salicylic acid also prevents the damaging action of various stress factors in many plant species $(37,38,39,40)$.

The aim of conducted this study to evaluate the hormones regulators $\left(\mathrm{GA}_{3}, \mathrm{SA}\right)$ and vitamin $\mathrm{C}$ (AsA) in improving the performance of three cultivars by seed priming in laboratory and field conditions.

\section{Materials and methods}


The study is based on the implementation of two experiments, one of which is complementary to the other. In the first experiment (laboratory), the germination characteristics of three bread wheat varieties are studied under the effect of five priming treatments with control treatment as dry seeds. In the field experiment the same factors were studied and their effects are on growth and yield at field conditions. Both of two experiments were conducted at the colleage of applied technical sciences of Halabajh - Sulaymaniyah ( Kurdstan province of Iraq).

\section{First: Laboratory experiment}

The characteristics of germination of three varieties of bread wheat(KALAL2, KUAZ , ADANA) obtained from the Directorate of Agricultural Research in Sulaymaniyah / Bakrajo will be studied under the effect of four factors of seed priming in addition treatment of comparison, the experiment consists of two factors (3 varieties) and five priming factors Including the control treatment( dry seeds), distilled water, GA (Gibberellin), ( SA) Salicylic acid, AsA ( Ascorbic acid))as $50 \mathrm{ppm}$ for each the last three priming factors, the laboratory experiment will be as factorial experiment according to the complete random design (CRD) with three replicates. 25 seeds of each treatment were prepared with three replicates. Seeds were sterilized before the priming process with sodium chloride solution at 5\% concentration for 1 minute $(5 \mathrm{ml}$ per $100 \mathrm{ml}$ ). The seeds are then thoroughly washed with distilled water. All priming solutions were prepared with distilled water and within the pre-installed concentrations. Two layers of filter paper were placed below the petri dishes while one layer of filter paper was placed on top of the seeds. The two bottom sheets were moistened in advance and $10 \mathrm{ml}$ of the priming solution and each treatment were seeded. The petri dishes were placed in the germinator at $25 \mathrm{C}^{0}$ for germination test. The following laboratory traits were studied in the laboratory after the end of the germination period: The first count of germination: After three days, the number of germinated seed is calculated and divided by the number of total seeds grown and calculated as a percentage.( The seed was considered to be germinated after three days at the radicle length about $2 \mathrm{~mm}$ ) Final percentage of germination: It represents the rate of dividing the number of normal seedlings at the end of the test after seven days on the total number of seeds. Length of the plumule $(\mathrm{cm})$, Length of the radicle $(\mathrm{cm})$, The vigor of seedling index $=$ germination ratio $\times$ (length of the plumule + length of the radicle ), Dry weight seedling : After placing the seedling in small perforated bags with removal of the embryonic axes and put in the oven at $65^{\circ} \mathrm{C}$ for 48 hours until the weight is stable.

\section{Second : The Field Experiment}

The second experiment in the field of the College of Technical Applied Sciences in Halabjah / Sulaymaniyah were carried out in the form of a factorial experience in the complete random block design (RCBD). It was included the same factors used in the laboratory experiment with three replicates, the experimental unit dimensions was $(2 \mathrm{~m} \times$ $1.40 \mathrm{~m} .2 .80 \mathrm{~m}$ 2) with 6 lines per experimental unit. The length of the line was $2 \mathrm{~m}$. The distance between the lines was $20 \mathrm{~cm}$. After the experiment land were prepared, The sowing was manual after the land is plowed, settled and softened, and the nitrogen and phosphorus containing fertilizer is added with the crop service operations and before planting. Service, fertilization, weeding control .The seeds were prepared and weighed in advance for the experimental units and based on the recommended seed rate of $120 \mathrm{~kg} /$ ha .The following characteristics were studied in the field experiment: percentage of field emergence $\%$,. number of spikes $/ \mathrm{m}^{2}$, number of spikelets / spike, number of grains / spike, Weight of 1000 kernel ( gm), grain yield (ton / ha).

\section{Statistical analysis}

The analysis of the statistical data for each experiment was performed according to the design of experiment which determined and according to the international experiments using computer according to the statistical analysis system (SAS - V9, 2002) (41). The mean of the transactions was compared with the Duncan (1955)(42) .The differences between the mean of the interference of the studied factors were tested according to this test, regardless of the significance of the $\mathrm{F}$ test. According to this test, the averages followed by similar alphabetic letters are not significantly different from each other and followed by different letters.

\section{Results and discussion}


Results of the laboratory experiment in (tables 1,2,3 and 4) showed superior most of the germination properties in the laboratory conditions, with more pronounced and significant in the priming treatment by ascorbic acid in its effect on the of germination characteristics compared to other treatments where the treatment with ascorbic acid was highest in the percentage of germination in the first count (93.122\%), the dry weight of seedling (16.344 $\mathrm{mg}$ ), the final germination rate $(93.400 \%)$ and the index of the seedling vigor $(16.382 \%)$ compared to the control treatment (dry seeds), which gave the lowest rates of germination in the first count (90.044), the dry weight of seedling(15.043 mg), the final germination rate $(90.700 \%)$ and the seedling vigor index(15.227\%), this shows the effect of ascorbic acid in reducing the time of germination and then take enough time for the development of the seedling that reflected on the weight of it and thus affecting in rate of final germination, and this is due to the role of ascorbic acid in that it promotes the process of germination through its effect in the availability of other necessary hormones in the process of germination, as well as being important factor as antioxidant in the process of oxidation in cells and this is supported by several previous studies $(25,26,27,28,31)$.

Table (1): effect of varieties and priming treatments on germination percentage in the first count \%

\begin{tabular}{|c|c|c|c|c|}
\hline Varieties & $\mathbf{V}_{\mathbf{1}}$ & $\mathbf{V}_{\mathbf{2}}$ & $\mathbf{V}_{\mathbf{3}}$ & Mean \\
\hline $\mathbf{P}_{\mathbf{0}}$ & $\mathrm{d} 85.633$ & $\mathrm{~d} 87.333$ & $\mathrm{~d} 87.233$ & $\mathrm{~b} 90.044$ \\
\hline $\mathbf{P}_{\mathbf{1}}$ & $\mathrm{c} 91.433$ & $\mathrm{c} 91.433$ & $\mathrm{c} 91.500$ & $\mathrm{~b} 90.733$ \\
\hline $\mathbf{P}_{\mathbf{2}}$ & $\mathrm{a} 94.967$ & $\mathrm{c} 91.733$ & $\mathrm{abc} 93.700$ & $\mathrm{a} 92.744$ \\
\hline $\mathbf{P}_{\mathbf{3}}$ & $\mathrm{abc} 93.033$ & $\mathrm{abc} 93.533$ & $\mathrm{bc} 92.100$ & $\mathrm{~b} 91.1667$ \\
\hline $\mathbf{P}_{\mathbf{4}}$ & $\mathrm{abc} 92.400$ & $\mathrm{abc} 92.967$ & $\mathrm{ab} 94.433$ & $\mathrm{a} 93.1222$ \\
\hline Mean & $\mathrm{a} 92.9267$ & $\mathrm{~b} 88.6267$ & $\mathrm{a} 93.1333$ & \\
\hline
\end{tabular}

dry seeds $\mathrm{P}_{1}$ : distilled water $\mathrm{P}_{2}$ : $\mathrm{GA}_{3} \mathrm{P}_{3}$ : $\mathrm{SA} \quad \mathrm{P}_{4}$ : AsA $\mathrm{V}_{1}$ : KALAL $\mathrm{V}_{2}$ : KUAZ $\mathrm{V}_{3}$ : ADANA

Table (2): effect of varieties and priming treatments on seedling dry weight ( $\mathrm{mg}$ )

\begin{tabular}{|c|c|c|c|c|}
\hline Treatment & $\mathbf{V}_{1}$ & $\mathbf{V}_{2}$ & $V_{3}$ & Mean \\
\hline $\mathbf{P}_{0}$ & fg 13.240 & g 12.903 & efg 13.956 & b 15.0433 \\
\hline $\mathbf{P}_{1}$ & a-e 16.043 & bcd 15.816 & def 14.5800 & b 15.2322 \\
\hline $\mathbf{P}_{2}$ & abc 16.326 & cde 14.890 & ab 16.906 & b $\quad 15.2800$ \\
\hline $\mathbf{P}_{3}$ & a-d 15.916 & bcd 15.696 & ab 16.606 & ab $\quad 15.801$ \\
\hline $\mathbf{P}_{4}$ & a-d 15.993 & ab 16.890 & a $\quad 17.336$ & a 16.3444 \\
\hline Mean & b 15.7647 & c 14.0993 & a 16.7567 & \\
\hline
\end{tabular}




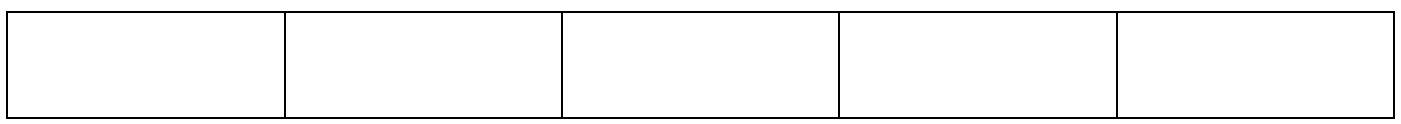

laboratory results also showed that Adana cv. was superior in all the laboratory characteristics of the other two cultivars, the highest germination rate in the first count $93.133 \%$ )( , the highest dry weight of the seedling( 16.756 $\mathrm{mg}$ ), the highest rate of final germination rate( $95.193 \%)$, Kuaz gave the lowest rates for the properties of germination mentioned above $(88.626 \%)(14.099 \mathrm{mg})(88.313 \%)$ respectively. These results are due to the different genotypes of the varieties used in the study, which is reflected in the difference in their response to the characteristics of germination in the laboratory conditions according to their genetic behavior. Many previous studies correspond to this finding ( 6 ,7,8,12,14,15,16 ).

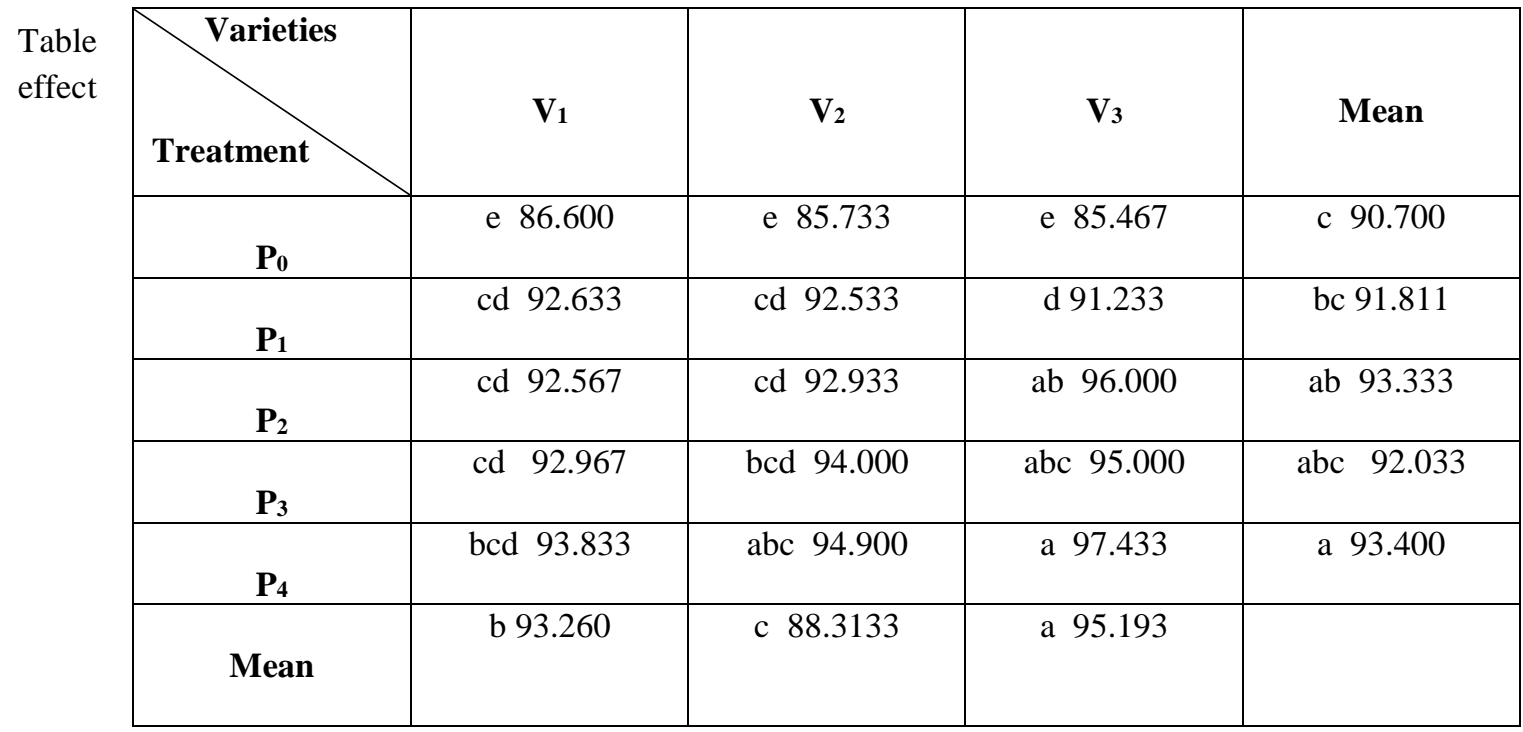

varieties and priming treatments on germination percentage of the final count $\%$ 
Table (4): effect of varieties and priming treatments on seedling vigor index \%

Results of the interaction between the priming factors and the varieties were shown in the germination properties, as the treatment of ascorbic acid with $\mathrm{cv}$. ADANA gave the highest rate of germination traits studied in the laboratory, the highest rate of germination in the final count (97.433\%) highest rate of dry weight of the seedling ( $17.336 \mathrm{mg}$ ), the highest rate of seedling vigor index ( $18.316 \%$ ), while the lowest dry weight of the seedling ( $12.903 \mathrm{mg}$ )and the lowest index of the seedling vigor( $12.206 \%$ ) were obtained in the control treatment (dry seeds) and with the KUAZ cv. This clearly illustrates the effect of the specific cultivar that superior in the most of the laboratory characteristics when it is placed with the appropriate priming treatment which gave the highest rates and therefore reflected on the evolution of all the characteristics of laboratory germination under the conditions of this treatment.

Table (5): effect of varieties and priming treatments on field emergence percentage\%

\begin{tabular}{|c|c|c|c|c|}
\hline Treatment & $\mathbf{V}_{\mathbf{1}}$ & $\mathbf{V}_{\mathbf{2}}$ & $\mathbf{V}_{\mathbf{3}}$ & Mean \\
\hline $\mathbf{P}_{\mathbf{0}}$ & $\mathrm{d} 14.260$ & $\mathrm{e} 12.206$ & $\mathrm{de} 13.500$ & $\mathrm{c} 15.227$ \\
\hline $\mathbf{P}_{\mathbf{1}}$ & $\mathrm{c} 15.680$ & $\mathrm{~d} 14.250$ & $\mathrm{~d} 14.013$ & bc 15.413 \\
\hline $\mathbf{P}_{\mathbf{2}}$ & bc 16.500 & bc 16.580 & ab 17.626 & ab 16.087 \\
\hline $\mathbf{P}_{\mathbf{3}}$ & abc 17.043 & abc 17.060 & abc 17.123 & a 16.227 \\
\hline $\mathbf{P}_{4}$ & abc 16.880 & abc 16.976 & a 18.316 & a 16.382 \\
\hline
\end{tabular}




\begin{tabular}{|l|l|l|l|l|}
\hline Mean & a 16.8127 & b 13.6460 & a 17.1447 & \\
\hline
\end{tabular}

\begin{tabular}{|c|c|c|c|c|c|}
\hline \multirow{7}{*}{$\begin{array}{l}\text { Table } \\
\text { effect }\end{array}$} & Treatment & $V_{1}$ & $\mathbf{V}_{2}$ & $V_{3}$ & Mean \\
\hline & $\mathbf{P}_{0}$ & e 74.333 & f 65.000 & e 75.000 & d 71.444 \\
\hline & $\mathbf{P}_{1}$ & $\operatorname{cd} 83.000$ & e 76.333 & a-d 86.333 & c 81.889 \\
\hline & $\mathbf{P}_{2}$ & cd 83.667 & bcd 84.333 & bcd 84.000 & bc 84.000 \\
\hline & $\mathbf{P}_{3}$ & a-d 86.000 & d 81.333 & abc 87.000 & b 84.778 \\
\hline & $\mathbf{P}_{4}$ & $\mathrm{ab} \quad 89.000$ & abc 88.000 & $\begin{array}{ll}\text { a } 90.333\end{array}$ & $\begin{array}{ll}\text { a } & 89.111\end{array}$ \\
\hline & Mean & a 83.200 & $\begin{array}{ll}\text { b } & 79.000\end{array}$ & a 84.533 & \\
\hline
\end{tabular}

(6):

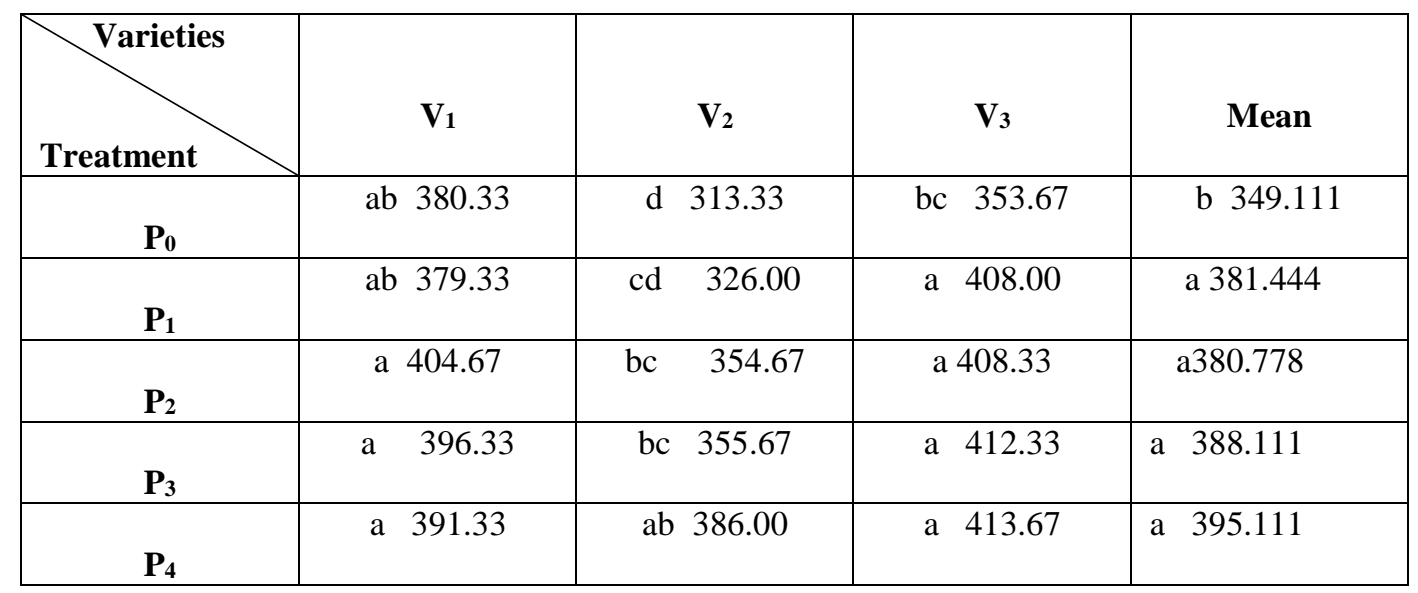




\begin{tabular}{|l|l|l|l|l|}
\hline Mean & a 390.400 & b 347.133 & a 399.200 & \\
\hline
\end{tabular}

The

results of the field experiment in (tables 5, 6, 7, 8, 9, and 10) indicated significant differences between priming treatments in all studied field traits. The treatment with ascorbic acid gave the highest rates of these traits, the highest rate of field emergence ( $89.111 \%)$, the highest rate of number of spikes / $\mathrm{m} 2$ (395.111 spike), the highest rate of number of grain per spike ( 69.922 grain), the highest rate of number of spikelets / spike( 20.633 spikelets), the highest rate of 1000 kernel weight $38.467 \mathrm{gm})$, the highest rate of grain yield ( 4.747 ton $/ \mathrm{ha})$, while the control treatment (dry seeds ) gave the lowest rates for these traits( $71.444 \%$ ) ( 349.111 spikes)( 58.800 grain) ( 19.077 spikelets)( 31.948 gm) ( 3.664 ton/ha) respectively, the result shows that the role of priming is not limited on the conditions of the laboratory, but reflected significantly on the percentage of field emergence, which leads to good field establishment of and the presence of strong plants, which enables the plants to compete under different conditions and give the optimal growth benefited from the plant in the transformation to increase dry material and optimal represented here in the grain yield, grain yield is the sum of the components for any crop affected by the treatment of ascorbic acid compared with other treatments that were also superior but less than the treatment of ascorbic acid. This result is consistent with the results of other studies( $25,27,31)$.

\begin{tabular}{|c|c|c|c|c|c|}
$\begin{array}{l}\text { Table } \\
\text { effect }\end{array}$ & \multicolumn{2}{|c|}{$\mathbf{V}_{\mathbf{1}}$} & \multicolumn{2}{|c|}{$\mathbf{V}_{\mathbf{2}}$} & \multicolumn{2}{|c|}{$\mathbf{V}_{\mathbf{3}}$} & Mean \\
\hline $\mathbf{P}_{\mathbf{0}}$ & $\mathrm{c} 61.633$ & $\mathrm{~d} 54.133$ & $\mathrm{c} 60.633$ & $\mathrm{c} 58.800$ \\
\hline $\mathbf{P}_{\mathbf{1}}$ & $\mathrm{c} 60.100$ & $\mathrm{bc} 64.633$ & $\mathrm{abc} 65.367$ & $\mathrm{~b} 63.367$ \\
\hline $\mathbf{P}_{\mathbf{2}}$ & $\mathrm{ab} 69.267$ & $\mathrm{ab} 68.367$ & $\mathrm{ab} 67.067$ & $\mathrm{a} 68.233$ \\
\hline $\mathbf{P}_{\mathbf{3}}$ & $\mathrm{ab} 67.667$ & $\mathrm{ab} 68.467$ & $\mathrm{ab} 68.500$ & $\mathrm{a} 68.211$ \\
\hline $\mathbf{P}_{\mathbf{4}}$ & $\mathrm{ab} 69.500$ & $\mathrm{ab} 69.767$ & $\mathrm{a} 70.500$ & $\mathrm{a} 69.922$ \\
\hline Mean & $\mathrm{a} 65.633$ & $\mathrm{a} 65.073$ & $\mathrm{a} 66.413$ & \\
\hline
\end{tabular}

of

varieties and priming treatments on number of grain per spike 
Table (8): effect of varieties and priming treatments on spikelets/ spike \%

\begin{tabular}{|c|c|c|c|c|}
\hline Varieties & $\mathbf{V}_{1}$ & $\mathbf{V}_{2}$ & $\mathbf{V}_{\mathbf{3}}$ & Mean \\
\hline Datict & fg 33.1000 & h 30.8300 & gh 31.9167 & c 31.9489 \\
\hline $\mathbf{P}_{1}$ & cd 35.1967 & bc 36.9600 & efg 33.4267 & b 35.1944 \\
\hline $\mathbf{P}_{2}$ & de 34.9733 & bcd 36.2467 & cd 35.3667 & b35.5289 \\
\hline $\mathbf{P}_{3}$ & fg 32.7767 & def 34.5133 & bc 36.8900 & b34.7267 \\
\hline $\mathbf{P}_{4}$ & a 38.7567 & ab 37.8667 & a 38.7800 & a 38.4678 \\
\hline Mean & a 35.2713 & b 34.5113 & a 35.7373 & \\
\hline
\end{tabular}

ADANA cv. achieved in the most studied field traits compared to the other two varieties, the highest rate of field emergence percentage ( $84.533 \%$ ), the highest number of ears / $\mathrm{m} 2$ ( 399.200 spike), the highest weight of 1000 grains $(35.737 \mathrm{gm})$, the highest weight of grain yield ( $4.646 \mathrm{ton} / \mathrm{ha})$. While the lowest rates for these traits were mentioned above in the KUAZ cv. ( 79.000\%) (347.133 spike)(34.511gm) (3.902 ton /ha)) respectively. This may be due to the genetic behavior for each cultivar that genotype assigned within a particular environment This corresponds to the results of other researchers $(6,7,8,12,14,15,16 \quad)$.

Table (9): effect of varieties and priming treatments on weight of 1000 kernel ( gm)

\begin{tabular}{|c|c|c|c|c|}
\hline Treatment & $\mathbf{V}_{\mathbf{1}}$ & $\mathbf{V}_{\mathbf{2}}$ & $\mathbf{V}_{\mathbf{3}}$ & Mean \\
\hline $\mathbf{P}_{\mathbf{0}}$ & $\mathrm{b} 18.333$ & $\mathrm{ab} 19.400$ & $\mathrm{ab} 19.500$ & $\mathrm{~b} \quad 19.077$ \\
\hline $\mathbf{P}_{\mathbf{1}}$ & $\mathrm{a} 20.633$ & $\mathrm{a} 20.700$ & $\mathrm{ab} 19.566$ & $\mathrm{a} \quad 20.300$ \\
\hline $\mathbf{P}_{\mathbf{2}}$ & $\mathrm{ab} 19.433$ & $\mathrm{a} 20.933$ & $\mathrm{ab} 20.200$ & $\mathrm{a} 20.188$ \\
\hline $\mathbf{P}_{\mathbf{3}}$ & $\mathrm{ab20.100}$ & $\mathrm{ab} 20.266$ & $\mathrm{ab} \mathrm{19.700}$ & $\mathrm{a} \mathrm{20.022}$ \\
\hline $\mathbf{P}_{\mathbf{4}}$ & $\mathrm{a} 20.500$ & $\mathrm{ab} 20.333$ & $\mathrm{a} 21.066$ & $\mathrm{a} \mathrm{20.633}$ \\
\hline
\end{tabular}




\begin{tabular}{c|c|c|c|c|c|}
\hline $\begin{array}{l}\text { Table } \\
\text { effect }\end{array}$ & Mean & a19.913 & a19.893 & a20.326 & (10): \\
of
\end{tabular}

varieties and priming treatments on grain yield ( ton / ha)

The effect of the interaction between ascorbic acid and ADANA cv. was the highest rate of field emergence

\begin{tabular}{|c|c|c|c|c|}
\hline Treatment & $\mathbf{V}_{\mathbf{1}}$ & $\mathbf{V}_{\mathbf{2}}$ & $\mathbf{V}_{\mathbf{3}}$ & Mean \\
\hline $\mathbf{P}_{\mathbf{0}}$ & $\mathrm{d} 3.5800$ & $\mathrm{e} 3.0233$ & $\mathrm{~d} 3.7200$ & $\mathrm{c} 3.6644$ \\
\hline $\mathbf{P}_{\mathbf{1}}$ & bcd 4.0800 & b 4.5033 & $\mathrm{~d} 3.6933$ & bc 3.8689 \\
\hline $\mathbf{P}_{\mathbf{2}}$ & bcd 4.1433 & d 3.7600 & bcd 4.2100 & b 4.0378 \\
\hline $\mathbf{P}_{\mathbf{3}}$ & a 5.4800 & b 4.6233 & bcd 4.1400 & $\mathrm{a} 4.7422$ \\
\hline $\mathbf{P}_{\mathbf{4}}$ & bc 4.4200 & cd 3.8600 & a 5.9467 & $\mathrm{a} 4.7478$ \\
\hline Mean & b 4.0880 & b 3.9027 & a 4.6460 & \\
\hline
\end{tabular}

percentage, number of spikes / $\mathrm{m}$ 2, number of grains per spike, number of spikelets /spike, weight of 1000 kernel, grain yield $(90.333 \%)$ ( 413.67 spike)( 70.500 grain ) ( 21.066 spikelets) ( 38.780 gm) ( 5.946 ton/ha) Respectively, while the treatment of the interaction between the control treatment (dry seeds ) and KUAZ cv. gave the lowest rate for the above traits $(65.000 \%$ ) ( 313.33 spike) ( 54.133 grain ) ( $30.830 \mathrm{gm}$ ) (3.023 ton /ha) respectively. This was 
explained to the response of the variety to most field characteristics and therefore the effect of this in the interaction with the treatment of priming with ascorbic acid, which reflected the superiority of the response to this cultivar under the effect of this treatment.

\section{Conclusion}

From the investigated results that obtained from this study we conclude that the priming with ascorbic acid was the highest effect between the others treatments in both of germination and field characters, in future studies we may suggest the priming of the seeds with ascorbic acid as a helpful and effective factor in achieving the development of both laboratory and field traits, with the recommendation to use the Adana variety as a promising species under the conditions of the arid zone of northern Iraq, with emphasis on future studies on the feasibility of the priming process in drought conditions and the retention of rain using the same stimulants or other priming factors.

\section{References}

1. Ahmad, N., N. H. Shah., Habibullah and F. U. Khan. 2005. Effect of different seed rates, sowing dates and weed control on grain yield of wheat. Pak. J. Weed Sci. Res., 11 (3-4): 19-23.

2. FAO, 2009. Food and Agriculture Organization of the United Nation (FAO). statistical databases.agriculture (available at http://apps.fao.org).

3. Parera C., A. and Cantliffe D. J. 1994. Pre-sowing seed priming. Hortic. Rev. 16: 109-141.

4. Heydecker W, Higgins J, Gulliver RL. Accelerated germination by osmotic seed treatment. Nature. 1973; 246:4246.

5.Bradford, K. J., 1986: Manipulation of seed water relations via osmotic priming to improve germination under stress conditions. Hort. Sci. 21, 1105-1112.

6. Farooq, M., S. M. A. Basra, A. Wahid, A. Khaliq, and N. Kobayashi, 2009c: ed. Organic Farming, Pest Control and Remediation of Rice seed invigoration: a review. In: E. Lichtfouse, Soil Pollutants, pp. 137-175. Springer, the Netherlands.

7. Kaya, M. D., G. Okc,ub, M. Ataka, Y. C, 1kılıc, and O. Kolsarıc1a, 2006: Seed treatments to overcome salt and drought stress during germination in sunflower (Helianthus annuus L.). Eur. J. Agron. 24, 291-295.

8. Farooq, M., A. Wahid, S. M. A. Basra, and K. H. M. Siddique, 2010: Improving crop resistance to abiotic stresses through seed invigoration. In: M. Pessarakli, ed. Handbook of Plant and Crop Stress, 3rd edn, pp. 1031-1050. Taylor and Francis Group, Boca Raton, FL, USA.

9. Farooq, M., S. M. A. Basra, H. Rehman, and B. A. Saleem, 2008b: Seed priming enhances the performance of late sown wheat (Triticum aestivum L.) by improving the chilling tolerance. Agron. Crop Sci. 194, 55-60.

10. Farooq, M., T. Aziz, M. Hussain, H. Rehman, K. Jabran, and M. B. Khan, 2008c: Glycinebetaine improves chilling tolerance in hybrid maize. Agron. Crop Sci. 194, 152-160 
11. Jafar, M. Z., M. Farooq, M. A. Cheema, I. Afzal, S. M. A. Basra, M. A. Wahid, T. Aziz, and M. Shahid, 2012: Improving the performance of wheat by seed priming under saline conditions. Agron. Crop Sci. 198, 38-45.

12. Brocklehurst, P. A., J. Dearman, and R. L. K. Drew, 1984: Effects of osmotic priming on seed germination and seedling growth in leek. Sci. Hort. 24, 201-210.

13. Brocklehurst, P. A., and J. Dearman, 2008: Interaction between seed priming treatments and nine seed lots of carrot, celery and onion II. Seedling emergence and plant growth. Ann Appl. Biol. 102, 583-593.

14. Farooq, M., S. M. A. Basra, M. Khalid, R. Tabassum, and T. Mehmood, 2006a: Nutrient homeostasis, metabolism of reserves and seedling vigor as affected by seed priming in coarse rice. Can. J. Bot. 84, 1196-1202.

15. Burgass, R. W., and A. A. Powell, 1984: Evidence for repair processes in the invigoration of seeds by hydration. Ann. Appl. Biol. 53, 753-757.

16.Bray, C. M., P. A. Davision, M. Ashraf, and R. M. Taylor, 1989: Biochemical changes during osmopriming of leak seeds. Ann. Bot. 6, 185-193.

17.Harris D, Rashid A, Hollington A, Jasi L, Riches C. Prospects of improving maize yield with on farm seed priming. In Rajbhandari, N.P. and Ransom, J.K. 'Sustainable Maize Production Systems for Nepal' NARC and CIMMYT, Kathmandu. 2007, 180-185.

18. Pedranzani, H.; Racagni, G.; Alemano, S.; Miersch, O.; Ramírez, I.; Peña-Cortés, H.; Taleisnik, H. E.; MachadoDomenech, E. and Abdala, E. G. (2003). Salt tolerant tomato plants show increased levels of jasmonic acid. Plant Growth Regulation. 4, 149-158.

19. Alonso-Ramírez, A., Rodríguez, D., Reyes, D., Jiménez, A.J., Nicolás, G., López-Climent, M., Gómez-Cadenas, A., and Nicolás, C. 2009. Evidence for a role of gibberellins in salicylic acid-modulated early plant responses to abiotic stress in Arabidopsis seeds. Plant Physiology. 150: 1335-1344.

20. Kabar, K., and Baltepe, S. 1987. Alleviation of salinity stress on germination of barley seeds by plant growth regulators. Turkish Journal of Biology. 11:108-117.

21.Batool, E. J. A. Z., Sajid, Z. A., \& Aftab, F. 2012. Effect of exogenous application of ascorbic acid on antioxidant enzyme activities, proline contents, and growth parameters of Saccharum spp. hybrid cv. HSF-240 under salt stress. Turkish Journal of Biology. 36(6): 630-640.

22.Azooz, M. M., Alzahrani, A. M., and Youssef, M. M. 2013. The potential role of seed priming with ascorbic acid and nicotinamide and their interactions to enhance salt tolerance in broad bean (Vicia faba L.). Aust J Crop Sci., 7(13): 2091-2100.

23. Conklin, P.L. and C. Barth. 2004. Ascorbic acid, a familiar small molecule intertwined in the response of plants to ozone, pathogens and the onset of senescence. Plant Cell Environ., 27: 959-971.

24.Khan, A., M.S.A. Ahmad, H.R. Athar and M. Ashraf. 2006. Interactive effect of foliar applied ascorbic acid and salt stress on wheat (Triticum aestivum L.) at seedling stage. Pak. J. Bot., 38(5): 1407-1414. 
25. Arrigoni, O., De., and M.C. Tullio. 2000. The role of ascorbic acid in cell metabolism: between gene-directed functions and unpredictable chemical reactions. Journal of Plant Physiology157: 481-488.

26. Barth, D.E., M. Tullio, and P.L. Conklin. 2006. The role of ascorbic acid in the control of flowering time and the onset of senescence. J. Exp. Bot., 57: 1657-1665.

27 De-Gara, L., M. C. De-Pinto, V. M. C. Moliterni, and M. G. D-Egidio, 2003: Redox regulation and storage processes during maturation in kernels of Triticum durum. J. Exp. Bot. 54, 249-258.

28.Arrigoni, O., G. Calabrese, L. De-Gara, M. B. Bitonti, and R. Liso, 1997: Correlation between changes in cell ascorbate and growth of Lupinus albus seedlings. J. Plant Physiol. 150, 302-308.

29. Mu"ller-Moule', P., M. Havaux, and K. K. Niyogi, 2003: Zeaxanthin deficiency enhances the high light sensitivity of an ascorbate-deficient mutant of Arabidopsis. Plant Physio.1133, 748-760.

30.Mu'ller-Moule', P., T. Golan, and K. K. Niyogi, 2004: Ascorbate- deficient mutants of Arabidopsis grow in high light despite chronic photooxidative stress. Plant Physiol. 134, 1163-1172.

31.Chen, Z., and D. R. Gallie, 2004: The ascorbic acid redox state controls guard cell signaling and stomatal movement. Plant Cell 16, 1143-1162.

32. Cutt, J.R. and D.F. Klessing. 1992. Salicylic acid in plants. A changing perspective. J. Pharm. Sci. Tech., 16: 2534.

33.Barkosky, R.R., and F.A. Einhellig. 1993. Effects of salicylic acid on plant water relationship. Journal of Chemical Ecology 19: 237-247.

34. Khan, M.A., and Z. Abdullah. 2003. Salinity-sodicity induced changes in reproductive physiology of rice (Oryza sativa) under dense soil conditions. Environmental and Experimental Botany 49: 145-157.

35. Mahmood, T., N. Iqbal, H. Raza, M. Qasim and M.Y. Ashraf. 2010. Growth modulation and ion partitioning in salt stressed sorghum (sorghum bicolour L.) by exogenously supply of salicylic acid. Pak. J. Bot., 42: 3047-3054.

36. Rafique, M., Raza, S. H., Qasim, M. and Iqbal, N. 2011. Pre-sowing application of ascorbic acid and salicylic acid to seed of pumpkin and seedling response to salt. Pakistan J. of Botany., 43(6): 2677-2682.I

37. Sakhabutdinova, A.R., D.R. Fatkhutdinova., M.V. Bezrukova., and F.M. Shakirova. 2003. Salicylic acid prevents the damaging action of stress factors on wheat plants. Bulgarian Journal of Plant Physiology, Special Issue 314-319.

38.Afzal, I., S. M. A. Basra, N. Ahmad, and M. Farooq, 2005: Optimization of hormonal priming techniques for alleviation of salinity stress in wheat (Triticum aestivum L.). Caderno de Pesquisa se'rie Biologia 17, 95-109.

39. Iqbal, M., and Ashraf, M. 2010b. Changes in hormonal balance: A possible mechanism of re-sowing chillinginduced salt tolerance in spring wheat. Journal of Agronomy and Crop Science 196: 440-454.

40. Iqbal M, Ashraf M,Jamil A and ur-Rehman S. 2006. Does seed priming induce changes in the levels of some endogenous plant hormones in hexaploid wheat plants under salt stress. J. Integr. Plant Biol.., 48: 181-189. 
41.Duncan, D.V., 1955. Multiple range test and multiple F test. Biometrics, 11: 1-42.

42.SAS Institute, (2002). The SAS system for Windos v. 9.00 SAS Institute Inc., Cary, NC, Usa. 